\title{
Structure and grazing of the microzooplankton communities of the Subtropical Convergence and a warm-core eddy in the Atlantic sector of the Southern Ocean
}

\author{
P. W. Froneman*, R. Perissinotto** \\ Southern Ocean Group, Department of Zoology and Entomology, Rhodes University, Box 94, Grahamstown 6140, South Africa
}

\begin{abstract}
The structure and grazing dynamics of microzooplankton were investigated at 15 stations during the SAAMES III cruise to the region of the Subtropical Convergence (STC) and across a warmcore eddy in subantarctic waters during austral winter (June/July) 1993. Microzooplankton abundance co-varied with the combined concentration of the nano- and picophytoplankton size fractions. Nanoflagellates dominated numerically at all stations while the $>20 \mu \mathrm{m}$ fraction was generally dominated by ciliates (oligotrichs and tintinnids). Mixotrophs comprised between 0 and $5 \%$ of total chlorophyll concentration. Production in the region showed a weak seasonal trend with the exception of stations in the vicinity of the STC. Instantaneous growth and grazing coefficients exhibited clear spatial trends, with the highest rates recorded at the edge of the eddy and in the region of the STC. Instantaneous grazing rates at stations at the edge of the eddy and at the STC varied from 0.347 to $0.701 \mathrm{~d}^{-1}$, equivalent to a loss of 30 to $51 \%$ of the initial standing stock and between 56 and $69 \%$ of the potential primary production. In the warm-core eddy, subantarctic and Agulhas waters, instantaneous grazing rates ranged from 0.281 to $0.433 \mathrm{~d}^{-1}$. This is equivalent to a loss of 24 to $35 \%$ of the initial standing stock and between 59 and $83 \%$ of the potential primary production. Size selectivity experiments suggest that microzooplankton preferentially graze on the pico-and nanophytoplankton size fractions. The results of this study show that the bulk of photosynthetically fixed carbon is channelled into the microbial loop during austral winter. This implies that the carbon pump is relatively inefficient during winter and that atmospheric $\mathrm{CO}_{2}$ drawdown via sinking of organic matter into deep water may be very limited in this area.
\end{abstract}

KEY WORDS: Southern Ocean Subtropical Convergence Microzooplankton grazing Biological pump

\section{INTRODUCTION}

The Subtropical Convergence (STC) is one of the major frontal systems of the Southern Ocean and constitutes its northern boundary (Deacon 1982, Lutjeharms \& Valentine 1988). Production in the region of the front shows no seasonal trends, with periods of elevated production alternating with periods of lower production throughout the year (Comiso et al. 1993) According to Dower \& Lucas (1993), the STC may rep-

-E-mail: zopf@warthog.ru.ac.za

- Present address: Department of Zoology, University of Fort Hare, Private Bag x 1314, A.lice 5700, South Africa resent an important biogenic sink for atmospheric $\mathrm{CO}_{2}$ and may account for between 0.5 and $0.8 \%$ of the total global ocean production.

The interaction of the Agulhas Retroflection Current (ARC) with the northern boundary of the STC in the oceanic region south of Africa results in a high variability in currents and the formation and shedding of warm-core eddies (Lutjeharms \& Valentine 1988, Duncombe Rae 1991). These eddies subsequently move southwards across the STC, contributing to meridional heat flux into the Southern Ocean and to the transfer of salt between the south Indian Ucean and the south Atlantic (Lutjeharms \& Gordon 1987, Duncombe Rae 1991). Although the effects of these eddies on the 
physico-chemical parameters of the region have been the subject of several investigations (Lutjeharms \& Gordon 1987, Lutjeharms \& Valentine 1988, Duncombe Rae 1991), their effects on the biological processes have largely been neglected in the past.

Studies on the effects of eddies on biological. processes elsewhere, and particularly in the Gulf Stream and East Australian Current, have demonstrated that eddies may result in localised areas of increased phytoplankton productivity (Tranter et al. 1980, Angel \& Fasham 1983, Smith \& Baker 1985, Franks et al. 1986) and may be important in the transportation of biological populations between different water masses (Angel \& Fasham 1983). Possible ecological consequences of eddy shedding from the ARC may be the transportation of warm water species across the STC, which is regarded as an important biogeographical barrier (Deacon 1982). Also, indirectly these eddies may result in changes in heat and $\mathrm{CO}_{2}$ flux which could influence the productivity of the region. A recent study by Dower \& Lucas (1993) found enhanced productivity rates at the edge of a warm-core eddy shed from the $A R C$, in generally low productive subantarctic waters.

Several field studies have demonstrated the importance of microzooplankton in the marine environment (see reviews of Porter et al. 1985, Garrison 1991, Pierce \& Turner 1992). In the Southern Ocean, a recent study by Froneman \& Perissinotto (in press) suggests that the impact of microzooplankton on phytoplankton stock may be determined by the contribution of smaller fractions (nano- and picophytoplankton) to total chlorophyll concentration. Indeed, it is well documented that in coastal environments where the phytoplankton are dominated by pico- and nanoplankton, protozooplankton are often the most significant herbivores (Capriulo \& Carpenter 1980, Burkill et al. 1987). This implies that the impact of microzooplankton on the carbon flux of the Southern Ocean may shift seasonally, since the contribution of the net phytoplankton to total chlorophyll decreases during austral winter, when the nanoand picophytoplankton dominate chlorophyli concentration (Garrison et al. 1993). This may have important implications for the $\mathrm{CO}_{2}$ flux, as a food web dominated by microzooplankton grazing is characterised by little sedimentation of particulate organic carbon (POC) out of the zone of regeneration where it is recycled by the microbial loop (Michaels \& Silver 1988, Longhurst \& Harrison 1989, Longhurst 1991). Consequently, the transfer of atmospheric $\mathrm{CO}_{2}$ into deep waters may be reduced. In order to have a better understanding of the Southern Ocean system as a potential biogenic sink for atmospheric $\mathrm{CO}_{2}$, it is therefore essential that possible seasonal effects be investigated.

The community structure and grazing impact of microzooplankton in the region of the STC and in a warm-core eddy shed from the ARC were investigated during austral winter (June/July) 1993. Grazing rates were determined at 15 stations.

\section{MATERIALS AND METHODS}

Microzooplankton grazing experiments were conducted during the third cruise of the South African Antarctic Marine Ecosystem Study (SAAMES III) aboard the MV 'S. A. Agulhas' in mid-austral winter (June/July) 1993 (Fig. 1). Grazing experiments were carried out using water from the surface layer $(5 \mathrm{~m})$, by employing the sequential dilution technique (Landry \& Hassett 1982).

Water samples were obtained using a submersible pump (Flyght-kyokuto model L 40-25S), operated at a flow rate of $\sim 151 \mathrm{~min}^{-1}$ and supplied to 251 polyethylene containers through PVC piping. The water was then passed through a $200 \mu \mathrm{m}$ mesh to separate the microzooplankton fraction. Particle-free water was obtained by passing surface water through a $0.2 \mu \mathrm{m}$ Milli-Q system (Millipore, Bedford, MA, USA). Dilution series in $2 \mathrm{l}$ acid-washed polyethylene bottles of

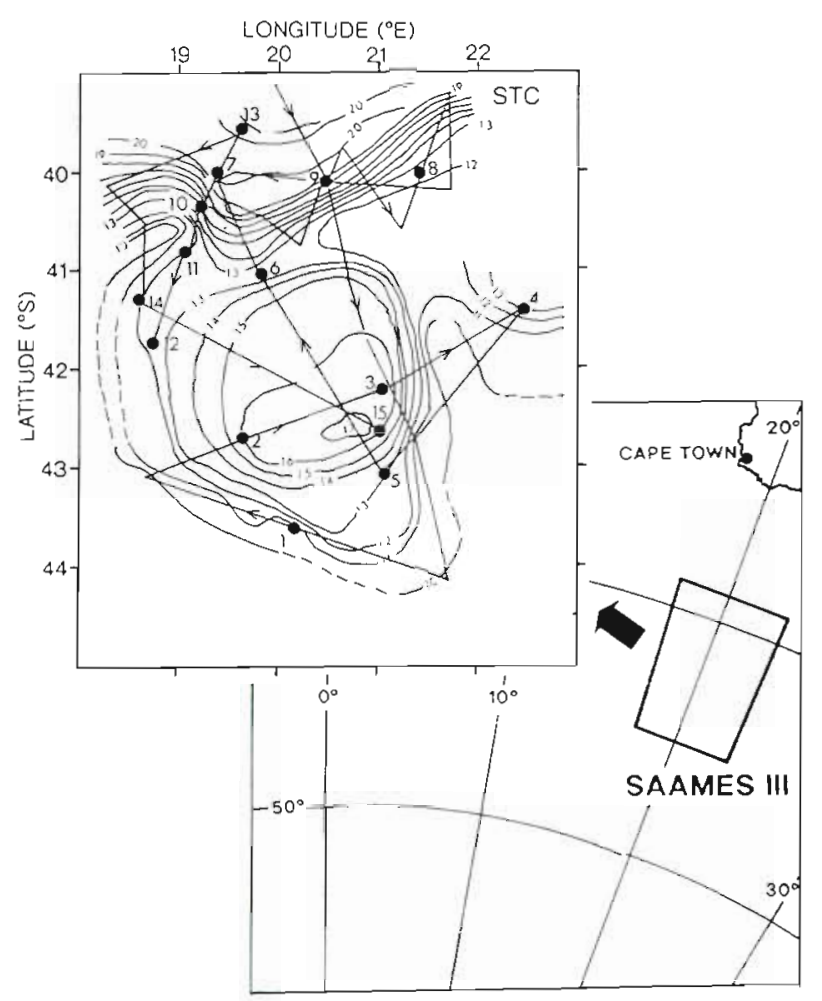

Fig. 1. Cruise track and position of stations (every station numbered, during the SAAMES III cruise aboard the MV 'S. A. Agulhas' in late austral winter in the Atlantic sector of the Southern Ocean. STC. Subtropical Convergence. Contours are sea surface temperatures 
$1: 0 ; 3: 1 ; 1: 1 ; 1: 3$ filtered to particle-free water were made. Three replicas of each dilution series were prepared. The dilution series were then incubated on deck for $24 \mathrm{~h}$ in perspex incubators cooled with running surface water and screened with shade cloth to simulate light intensity (500 to $1300 \mu \mathrm{E} \mathrm{m}^{-2} \mathrm{~s}^{-1}$ ) at the depth of collection.

Before incubation was begun, water samples (250 $\mathrm{ml})$ for the determination of initial chlorophyll a concentration were taken from each bottle. Bottles were sampled again (250 ml) at the end of the incubation period to determine final chlorophyll a concentration. Chlorophyll a was then fractionated into the net-, nano- and picophytoplankton size fractions through multiple serial filtration. Size selectivity studies were also carried out in parallel. Using the same incubation settings, water samples taken from the 1:0 dilution series were fractionated into net, nano- and picophytoplankton size fractions at the onset and at the end of the incubation period. Chlorophyll a concentrations were determined fluorometrically (Turner 111 fluorometer), after extraction in 100\% methanol (HolmHansen \& Riemann 1978).

To identify and enumerate the various components of the microzooplankton community, a $50 \mathrm{ml}$ seawater sample was stained with Proflavine $\left(50 \mu \mathrm{ml}^{-1} ; 2 \mathrm{~min}\right)$, fixed with glutaraldehyde (final conc. $6 \%$ ) and then filtered (vacuum $\leq 13 \mathrm{~cm} \mathrm{Hg}$ ) through a $2.0 \mu \mathrm{m}$ Irgalan black prestained Nuclepore filter (Haas 1982). Permanent slides were then prepared according to the method of Booth (1987) and frozen at $-20^{\circ} \mathrm{C}$. Slides were examined within 2 mo after the cruise using a Zeiss fluorescent microscope equipped with a 450-490 excitation filter, a FT 510 chromatic beam splitter and a long pass 528 barrier filter operated at $400 \times$ magnification (Haas 1982). No significant loss in the autofluorescence of the chlorophyll-containing organisms was anticipated (Booth 1987). Phototrophic organisms were distinguished from heterotrophic organisms by the red autofluorecence of chlorophyll a (Haas 1982).

Microzooplankton were grouped into the following protozooplankton groups: tintinnids, aloricate ciliates, dinoflagellates, heterotrophic-nanoflagellates (h-nanoflagellates, $<20 \mu \mathrm{m}$ ) and mixotrophs. Enumerations were converted to cells $\mathrm{l}^{-1}$ by employing the equation of Waterbury et al. (1986):

$$
\text { No. cells in } 100 \text { fields } \times \frac{\text { (total area of filter) }}{\text { (area of } 100 \text { fields) }} \times 20
$$

Grazing rates of the microzooplankton on chlorophyll $a$ and potential production of the phytoplankton were calculated using the exnonential growth model of Landry \& Hassett (1982):

$$
P_{t}=P_{0} \mathrm{e}^{(k-g) t}
$$

where $P_{1}$ and $P_{0}$ are chlorophyll concentrations at time $t$ and 0 , and $k$ and $g$ are instantaneous coefficients of algal growth and grazing, respectively. The coefficients were determined by least-squares regression analysis (95\% confidence levels) employing the Statgraphics Version 5.0 computer package (Statistical Graphics Corporation USA 1989). Both $k$ and $g$ were used to calculate the grazing loss of potential daily production while only $g$ was used to estimate daily loss of initial standing stock (Landry \& Hassett 1982).

To normalise the chlorophyll values, all data were transformed using the factor $\log (x+1)$ (Legendre \& Legendre 1983). Also, grazing data expressed in \% were normalised by the arcsin transformation (Sokal \& Rolhf 1969). Partial correlation analysis was then performed on the grazing data to identify possible relationships between grazing rates, temperature and concentrations of chlorophyll size fractions (Sokal \& Rohlf 1969). The computer package Statgraphics Version 5.0 was again used for this analysis.

\section{RESULTS}

\section{Chlorophyll distribution}

Chlorophyll concentrations measured along the transect exhibited a clear spatial pattern. Highest concentrations $\left(>0.5 \mathrm{\mu g} \mathrm{l}^{-1}\right)$ were recorded at stations at the periphery of the eddy (Stns 6 and 12) and in the region of the STC (Stns 8 to 11) (Fig. 2). An exception was provided by Stn 1, located at the periphery of the eddy, where the lowest chlorophyll concentration

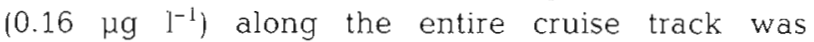
recorded. Stations in the warm-core eddy (Stns 2, 3, 5 and 15), in subantarctic (Stns 4 and 14) and Agulhas waters (Stns 7 and 13) were characterised by chlorophyll concentrations $<0.5 \mu \mathrm{g} \mathrm{l^{-1 }}$. The nano- and picophytoplankton size fractions dominated chlorophyll biomass at all stations (Fig. 2). The picophytoplankton in particular was the dominant component at all but 4 stations (Stns 1, 2, 9 and 10), where the nanophytoplankton dominated chlorophyll concentration. The contribution of the net-phytoplankton fraction to total chlorophyll concentration was $<10 \%$ at all stations with the exception of Stn 8 where it contributed $\sim 20 \%$ of the total.

\section{Community structure}

Microzooplankton abundance generally co-varied with the combined concentrations of the nano- and picophytoplankton (<20 $\mu \mathrm{m})$ size-fractions (Fig. 3). Indeed, $-35 \%$ of the variance associated with micro- 


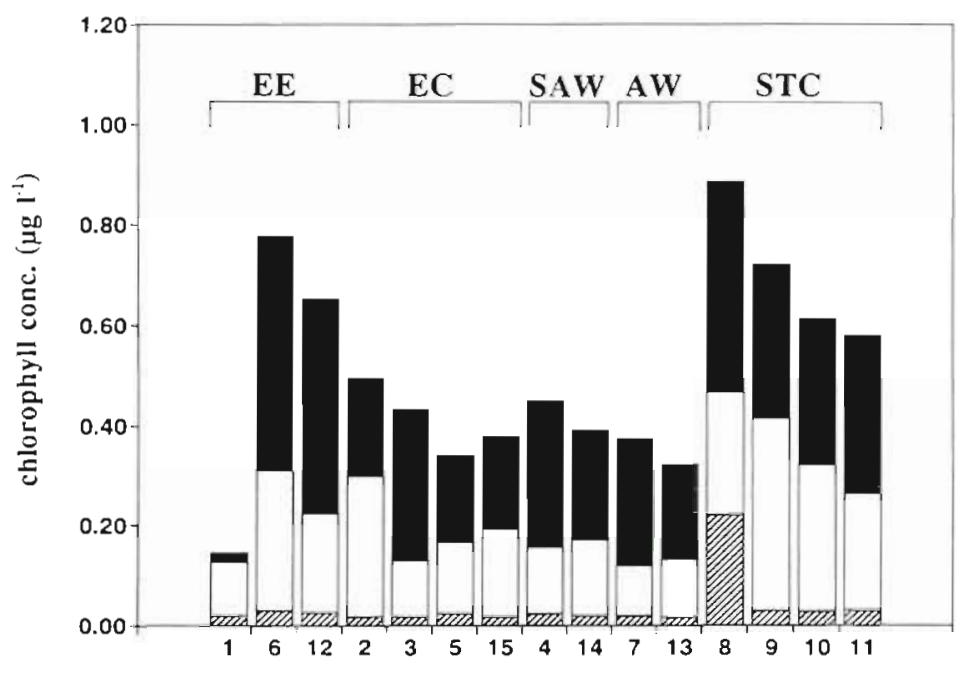

station

WWI netphytopiankton $\square$ nanophytoplankton $\square$ picophytoplankton

Fig. 2. Size-fractionated chlorophyll a in surface waters along the STC transect during the SAAMES III cruise (June/July 1993). EE: Eddy Edge; EC: Eddy Core; SAW: Subantarctic Waters; AW: Agulhas Waters; STC: Subtropical Convergence

zooplankton abundance could be described by the 0.2 to $20 \mu \mathrm{m}$ size fraction $(p<0.05)$.

$\mathrm{H}$-nanoflagellates $(<20 \mu \mathrm{m})$ dominated numerically at all stations (Table 1). Densities ranged between 106 and 403 ind. $\mathrm{l}^{-1}$. The $>20 \mu \mathrm{m}$ microzooplankton fraction was generally dominated by ciliates (oligotrichs and tintinnids), although dinoflagellates dominated at 5 of the 15 grazing stations (Table 1). The contribution of tintinnids to total ciliate densities was always less than the contribution of the oligotrichs. The least represented fraction was the plastidcontaining microzooplankton or mixotrophs, which comprised $<5 \%$ of total cell counts at all stations. Densities of this group never exceeded 14 ind. $\mathrm{l}^{-1}$.

\section{Microzooplankton grazing}

Instantaneous phytoplankton growth rates, grazing rates and regression coefficients for the grazing experiments at the various oceanographic areas are shown in Table 2. In all our experiments, significant linear regressions ( $p<0.05$ ) were found between dilution. and the apparent phytoplankton growth (Table 2). Both growth and grazing coefficients show similar spatial patterns with highest rates recorded at stations at the edge of the eddy and in the vicinity of the STC (Table 2).
Algal growth coefficients $(k)$ ranged from 0.548 to $1.317 \mathrm{~d}^{-1}$ at the edge of the warmcore eddy and from 1.214 to $1.476 \mathrm{~d}^{-1}$ at the STC (Table 2). These values are equivalent to chlorophyll doubling rates between 0.791 and $1.900 \mathrm{~d}^{-1}$ at the edge of the eddy, and between 1.751 and $2.129 \mathrm{~d}^{-1}$ at the STC. Within the warm-core eddy, algal growth coefficients ranged from 0.513 to $0.707 \mathrm{~d}^{-1}$ while within subantarctic waters they were lower, between 0.454 and $0.555 \mathrm{~d}^{-1}$ (Table 2). At stations in the Agulhas waters, the algal growth coefficients ranged from 0.471 to $0.581 \mathrm{~d}^{-1}$. This represents a chlorophyll doubling rate of 0.740 to $0.994 \mathrm{~d}^{-1}$ in the core of the eddy, from 0.654 to $0.800 \mathrm{~d}^{-1}$ in the subantarctic waters and from 0.708 to $0.838 \mathrm{~d}^{-1}$ in the Agulhas waters (Table 2)

Grazing coefficients of microzooplankton (a) were highest at stations at the periphery of the warm-core eddy (range: 0.347 to 0.701 $\mathrm{d}^{-1}$ ) and in the region of the STC (range: 0.531 to $0.716 \mathrm{~d}^{-1}$ ). This level of instantaneous grazing activity by microzooplankton represents a loss of between 29.38 and $51.12 \%$ of the initial standing stock at the edge of the warm-core eddy and at the STC, respectively (Table 2). The equivalent daily loss of potential production due to grazing in these regions was between 56.25 and $69.83 \%$ (Table 2).

Instantaneous grazing rates of microzooplankton ranged from 0.281 to $0.433 \mathrm{~d}^{-1}$ in the warm-core eddy, between 0.351 and $0.393 \mathrm{~d}^{-1}$ in subantarctic waters and from 0.297 to $0.331 \mathrm{~d}^{-1}$ in the Agulhas waters (Table 2). This level of grazing is equivalent to a loss of

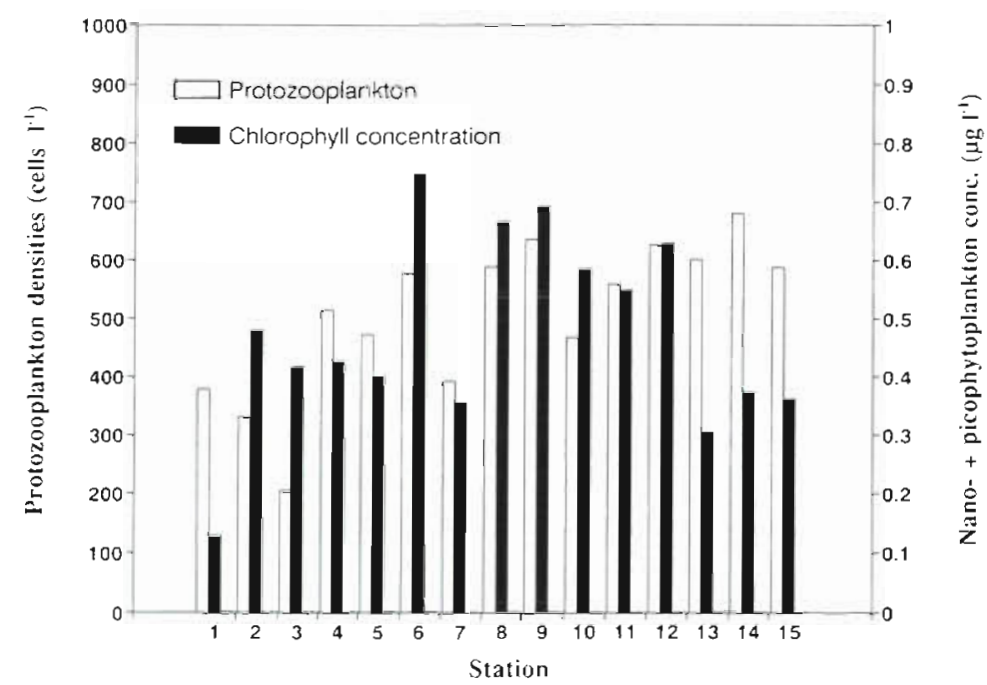

Fig. 3. Total microzooplankton abundance and combined concentrations of the nano- and picophytoplankton size classes along the SAAMES III transect 
Table 1. Abundance of heterotrophic protozooplankton at grazing stations during the SAAMES IIl cruise (June/July) 1993. Results expressed as ind. I

\begin{tabular}{|rrrrrr|}
\hline $\begin{array}{r}\text { Stn } \\
\text { no. }\end{array}$ & $\begin{array}{c}\text { Aloricate } \\
\text { ciliates }\end{array}$ & Tintinnids & $\begin{array}{c}\text { Dino } \\
\text { flagellates }\end{array}$ & $\begin{array}{c}\text { Nano- } \\
\text { heterotrophs }\end{array}$ & Mixotrophs \\
\hline 1 & 60 & 21 & 64 & 230 & 3 \\
2 & 53 & 13 & 71 & 186 & 9 \\
3 & 21 & 0 & 32 & 149 & 3 \\
4 & 92 & 0 & 96 & 319 & 7 \\
5 & 74 & 11 & 82 & 294 & 11 \\
6 & 67 & 7 & 57 & 343 & 3 \\
7 & 50 & 4 & 124 & 213 & 3 \\
8 & 22 & 4 & 27 & 106 & 0 \\
9 & 124 & 21 & 117 & 358 & 14 \\
10 & 82 & 25 & 50 & 305 & 7 \\
11 & 149 & 21 & 128 & 258 & 3 \\
12 & 133 & 11 & 112 & 357 & 14 \\
13 & 129 & 14 & 124 & 340 & 3 \\
14 & 124 & 3 & 146 & 403 & 7 \\
15 & 116 & 13 & 142 & 319 & 0 \\
\hline
\end{tabular}

and grazing impact of microzooplankton was significant $(t=10.04 ; \mathrm{p}<0.001)$.

\section{Size selectivity}

Microzooplankton preferentially grazed the smaller size fractions (Fig 4). Picophytoplankton was the most intensely grazed fraction, decreasing in concentration during grazing experiments at 11 of the 15 stations. Mean decrease in concentration along the cruise track was $20.8 \%$. Nanophytoplankton was the second most intensely grazed fraction, decreasing in concentration at 7 stations, with a mean decrease of $7.6 \%$ along the transect. Analysis of variance (ANOVA) and multiple range tests indicate that the \% picoand nanophytoplankton removed were not

between 24.55 and 33.33 of the initial standing stock in the 3 regions (Table 2). The potential primary production removed ranged between 61.83 and $82.63 \%$ of the total (Table 2).

Partial Correlation Analysis performed between grazing data and selected variables indicated that the initial standing stock removed was correlated positively to the concentrations of pico- $(t=3.31 ; p<0.001)$ and nanophytoplankton $(t=1.87 ; \mathrm{p}<0.05)$. Also, the relationship between growth rate of phytoplankton significantly different $(F=0.712 ; \mathrm{p}=0.41)$. The least grazed fraction was the netphytoplankton, which during the incubation period increased in concentration at 14 of the 15 stations examined (Fig. 4).

\section{DISCUSSION}

The role of microzooplankton in determining carbon flux in marine systems has been the subject of exten-

Table 2. Estimates of chlorophyll a concentrations, phytoplankton growth $\left(k, \mathrm{~d}^{-1}\right)$ and the grazing impact of microzooplankton ( $g$, $\mathrm{d}^{-}$) on the initial phytoplankton stock and potential production during the SAAMES III cruise to the region of the Subtropical Convergence in the Atlantic sector of the Southern Ocean in late austral winter (June/July) 1993. ${ }^{\circ} p<0.05 ;{ }^{*}{ }^{0}<0.001$ ). Values in parentheses: standard error. Chlorophyll doublings $d^{-1}=k / \ln 2$ (Glford 1988)

\begin{tabular}{|c|c|c|c|c|c|c|c|c|}
\hline $\begin{array}{l}\text { Oceanographic } \\
\text { area }\end{array}$ & Stn & $\begin{array}{l}\text { Chl a } \\
\text { conc. }\end{array}$ & $\mathrm{r}^{2}$ & $\begin{array}{c}\text { Growth coeff } \\
k\left(d^{-1}\right)\end{array}$ & $\begin{array}{l}\text { Grazing coeff } \\
\qquad g\left(\mathrm{~d}^{-1}\right)\end{array}$ & $\begin{array}{c}\% \text { initıal } \\
\text { stock removed }\end{array}$ & $\begin{array}{c}\% \text { potential } \\
\text { prod. removed }\end{array}$ & $\begin{array}{l}\text { Chlorophyll } \\
\text { doublings }\left(\mathrm{d}^{-1}\right)\end{array}$ \\
\hline \multirow[t]{3}{*}{ Eddy edge } & 1 & 0.160 & $0.48^{\circ}$ & $0.548(0.123)$ & $0.347(0.046)$ & 29.38 & 69.83 & 0.791 \\
\hline & 6 & 0.780 & $0.53^{\circ}$ & $1.317(0.178)$ & $0.701(0.091)$ & 50.38 & 68.84 & 1.900 \\
\hline & 12 & 0.656 & $0.76^{*}$ & $1.299(0.073)$ & $0.673(0.078)$ & 48.93 & 67.35 & 1.847 \\
\hline \multirow[t]{4}{*}{ Eddy core } & 2 & 0.498 & $0.66^{*} \cdot$ & $0.513(0.101)$ & $0.404(0.031)$ & 33.33 & 82.63 & 0.740 \\
\hline & 3 & 0.436 & $0.50^{\circ}$ & $0.707(0.039)$ & $0.376(0.071)$ & 31.42 & 61.83 & 1.019 \\
\hline & 5 & 0.395 & $0.55^{\circ}$ & $0.581(0.084)$ & $0.281(0.011)$ & 24.55 & 55.62 & 0.838 \\
\hline & 15 & 0.380 & $0.54^{\bullet}$ & $0.689(0.102)$ & $0.433(0.037)$ & 35.26 & 70.37 & 0.994 \\
\hline Agulhas & 7 & 0.376 & $0.67^{\cdots}$ & $0.471(0.081)$ & $0.339(0.044)$ & 28.45 & 77.73 & 0.708 \\
\hline waters & 13 & 0.321 & $0.57^{\circ}$ & $0.581(0.053)$ & $0.297(0.065)$ & 25.55 & 71.54 & 0.838 \\
\hline \multirow{2}{*}{$\begin{array}{l}\text { Subantarctic } \\
\text { waters }\end{array}$} & 4 & 0.450 & $0.66^{\bullet}$ & $0.454(0.098)$ & $0.351(0.013)$ & 29.56 & 81.08 & 0.654 \\
\hline & 14 & 0.393 & $0.35^{\circ}$ & $0.555(0.107)$ & $0.393(0.037)$ & 32.56 & 76.36 & 0.800 \\
\hline Subtropical & 8 & 0.889 & $0.89^{*}$ & $1.233(0.153)$ & $0.599(0.096)$ & 45.11 & 63.58 & 1.779 \\
\hline \multirow[t]{3}{*}{ Convergence } & 9 & 0.725 & $0.74 \cdots$ & $1.214(0.108)$ & 0.603 (U. 0800$)$ & 48.41 & 68.30 & 1.751 \\
\hline & 10 & 0.614 & $0.32^{\circ}$ & $1.318(0.127)$ & $0.531(0.073)$ & 41.21 & 56.25 & 1.901 \\
\hline & 11 & 0.581 & $0.39^{\circ}$ & $1.476(0.278)$ & $0.716(0.103)$ & 51.12 & 66.29 & 2.129 \\
\hline
\end{tabular}




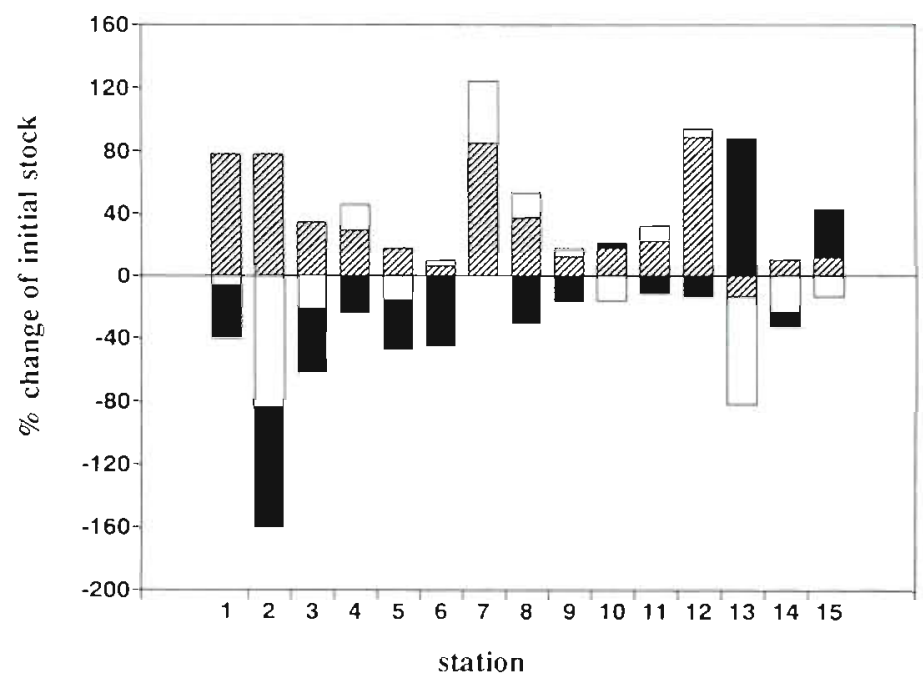

VII] netphytoplankton

Fig. 4. Results of size selectivity grazing studies. Results are expressed as percentage increase or decrease of initial concentrations

sive investigations (see review of Pierce \& Turner 1992). The results of many studies suggest that the impact of microzooplankton varies greatly over both spatial and temporal scales. Recent studies have shown that the impact of microzooplankton on phytoplankton standing stock is largely determined by the contribution of the smaller chlorophyll fractions to total chlorophyll concentration (Froneman \& Perissinotto in press). Indeed, microzooplankton may remove $>70 \%$ of potential primary production in subarctic regions where the $<20 \mu \mathrm{m}$ fractions dominate chlorophyll concentration (Paranjape 1987, Verity et al. 1993). During this study, microzooplankton removed $>50 \%$ of potential production, suggesting that microzooplankton may represent the major route for the uptake of organic carbon (Table 2). This is consistent with results from previous studies conducted in regions where the $<20 \mu \mathrm{m}$ chlorophyll fractions dominate chlorophyll biomass (see results of Gifford 1988).

The highest algal growth coefficients during the study were recorded in the areas of higher production, at the STC and at the edge of the warm-core eddy while the lowest coefficients were associated with the regions of lower production, in the subantarctic and Agulhas waters and in the core of the eddy (Table 2). Growth rates in winter were generally lower than summer growth rates, suggesting a seasonal influence on production (Froneman \& Perissinotto in press). The result is consistent with the size-fractionated primary production study (determined by measuring ${ }^{14} \mathrm{C}$ uptake) conducted simultaneously with the microzooplankton grazing studies (R. K. Laubscher unpubl.).
The exceptions presented were at stations in the vicinity of the STC where winter growth rates were in the same range as summer growth rates (Froneman \& Perissinotto in press). This result is consistent with the findings of Comiso et al. (1993) which demonstrated that production at the front shows no seasonal trends. Our estimates of algal growth in the low productive areas compare well with a similar study conducted in the Bransfield Strait (Taylor \& Haberstroh 1988). The high algal growth coefficients recorded at the STC and edge of the eddy are among the highest published values in the Southern Ocean. Elevated production in the region of the STC and at the edge of warm-core eddies are well documented and are thought to be the result of a favourable light environment conferred by increased water column stability (El-Sayed 1988, Comiso et al. 1993, Dower \& Lucas 1993). The spatial difierences in production rates and chlorophyll concentrations are reflected in the amount of initial standing stock and potential production removed daily by microzooplankton (Table 2).

The initial standing stock removed by microzooplankton grazing was highest at the edge of the warmcore eddy and in the region of the STC (Table 2). Several factors have been implicated in determining community grazing rates, including temperature, predator abundance, and ingestion rates as determined by the food concentration (Strom \& Welschmeyer 1991, Peters 1994). During the present study, the relationship between grazing impact and temperature was not significant $(p<0.05)$. However, the grazing impact of microzooplankton was significantly correlated to protozooplankton abundance (Fig. 5A) and to concentrations of the $<20 \mu \mathrm{m}$ chlorophyll fraction (Fig. 5B). These results suggest that the high grazing impact of microzooplankton at the edge of the eddy and in the vicinity of the STC results from the high predator/prey concentrations. Also, the close coupling between phytoplankton growth rates and grazing impact suggests that the phytoplankton/microzooplankton transfer efficiency will be high. Exceptions presented may reflect the wide range of trophic interactions of microzooplankton reported in the literature (Pierce \& Turner 1992, Peters 1994). For example, nonphytoplankton food suck as bacteria may represent an important trophic resource. Unfortunately, no information is available on microzooplankton bactivory.

The levels of potential primary production removed showed a weak inverse spatial pattern to the initial standing stock removed (Table 2). The lowest levels were recorded in the region of the STC and at the edge 

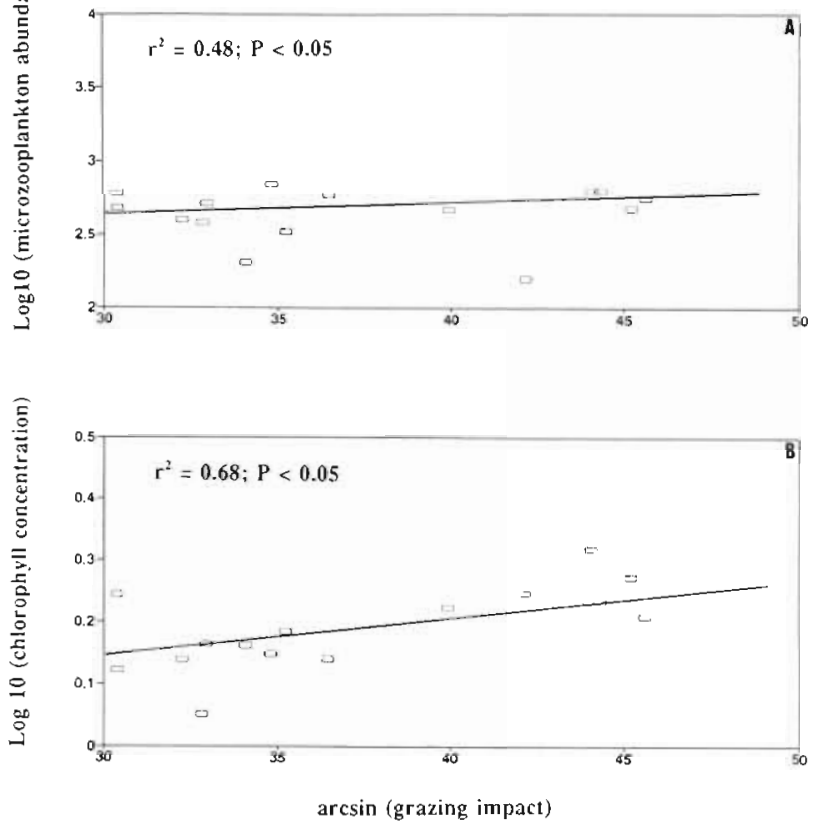

Fig. 5. Relationship between \% initial standing stock removed and (A) protozooplankton abundance and (B) $<20 \mu \mathrm{m}$ chlorophyll fraction during the SAAMES lI.l cruise in late austral winter (June/July) 1993

of the eddy (Table 2). The impact of microzooplankton grazing on potential algal production is largely determined by the growth phase of the algae (Banse 1991) Under favourable conditions, algal productivity exceeds microzooplankton grazing rates (i.e. $k>g$ ), resulting in the accumulation of phytoplankton biomass in the absence of larger grazers (Banse 1991). Phytoplankton production was highest at the edge of the warm-core eddy and in the region of the STC (Table 2). The impact of microzooplankton on potential algal production in these regions should be lower when compared to regions of lower production (subantarctic and Agulhas waters and in the warm-core eddy). Indeed, the mean potential primary production removed from the STC and the edge of the eddy was $-65 \%$, compared to $-73 \%$ in areas of lower productivity. These results compare favourably with microzooplankton grazing studies conducted in subarctic waters during a bloom, where 80 to $100 \%$ of the potential algal production was grazed when $-80 \%$ of the chlorophyll passed through a $10 \mu \mathrm{m}$ mesh (Verity et al. 1993)

The concentrations of the nano- and picophytoplankton size fractions decreased during the size selectivity grazing study (Fig. 4). An indication of the growth status of phytoplankton can be derived from the photosynthetic capacity (PC) value. Preliminary results of size-fractionated production studies conducted during the cruise indicate that chlorophyll-nor- malised production rates ( $\mathrm{PC}$ ) were highest in the picophytoplankton and nanophytoplankton size fractions (R. K. Laubscher unpubl.). The decreases in concentration of the nano- and picophytoplankton fractions suggest, therefore, that microzooplankton are preferentially grazing on particles $<20 \mu \mathrm{m}$. Indeed, during this study, the relationship between grazing impact and $<20 \mu \mathrm{m}$ chlorophyll fraction was significant $(p<0.05)$. This result is consistent with the community composition of the microzooplankton assemblages which were numerically dominated by nanoheterotrophs throughout the study (Table 1). Also, changes in the concentrations of the nano- and picophytoplankton were not significantly different, suggesting that microzooplankton are able to feed efficiently on all particles $<20 \mu \mathrm{m}$. It is well documented that nanoheterotrophs and ciliates consume particles $<20 \mu \mathrm{m}$ (Burkill et al. 1987, Rassoulzadegan et al. 1988, Verity \& Vernet 1993).

Densities of protozooplankton were $<1000$ ind. $\mathrm{I}^{-1}$ throughout the study (Table 1). Despite high food availability, densities were nearly an order of magnitude lower than during a similar study undertaken in austral summer (Froneman \& Perissinotto in press). Generally, in the region of the STC chlorophyll concentration shows no seasonal trends (Comiso et al. 1993). However, although absolute phytoplankton biomass does not vary seasonally, there is evidence suggesting that the composition of the phytoplankton changes from a community dominated by netphytoplankton in summer, to a community dominated by the nano- and picophytoplankton in winter (Hattori \& Fukuchi 1989, Laubscher et al. 1993). A recent study by Pakhomov et al. (1994) found high species richness and biomass in the macrozooplankton community in the region of the STC during winter, despite the absence of the netphytoplankton on which they normally feed. The low microzooplankton densities recorded during this survey may, therefore, be due to predation by larger zooplankton which may switch from herbivory to carnivory in the absence of their preferred food. A similar situation occurs in the Weddell and Scotia Seas, where zooplankton feed on microzooplankton during austral winter, when nanoautotrophs dominate chlorophyll concentrations (Garrison et al. 1993).

The mixotrophic component was the most poorly represented in the microzooplankton assemblage, exhibiting densities ranging from 0 to 14 ind. $\mathrm{l}^{-1}$ (Table 1). These low densities may be due to predation or to light limitation associated with seasonality. It is unlikely, therefore, that they contribute significantly to the primary production in the region. Assuming a chlorophyll a content of $\sim 21$ to $y 4$ pg per mixotropnic ciliate (Garrison et al. 1993), the mixotrophs would have accounted for 0 to $5 \%$ of total chlorophyll a con- 
centration. These estimates compare well with the results of Garrison et al. (1993), who found that mixotrophs comprise between 1 and $6 \%$ of the total chlorophyll of the ice edge zone of the Weddell and Scotia Seas during austral winter. The low densities of the mixotrophic component suggest that they may not play a significant role in community functioning with respect to carbon flux in. winter.

During this study, microzooplankton grazing in the region of the STC removed $>50 \%$ of all potential production (Table 2). This suggests that the greater part of photosynthetically fixed carbon in the region is channelled into the microzooplankton fraction. As a result, carbon flux into deep water may be reduced in that little sedimentation of organic carbon occurs as the minipellets produced by the microzooplankton remain in suspension. In addition, the faecal pellets are readily decomposed by bacteria in the microbial loop (Michaels \& Silver 1988). Bacteria in turn represent a large reservoir of carbon and nitrogen for bacterivores such as nanoheterotrophic flagellates (Andersen \& Fenchel 1984, Gast 1985, Albright et al. 1987, MCManus \& Furhman 1988, Reid \& Karl 1990, Kirchman et al. 1993). Consequently, POC flux below the zone of regeneration is reduced as the carbon is recycled within the microbial loop, resulting in the reduction of the biological drawdown of atmospheric $\mathrm{CO}_{2}$ in the region (Longhurst \& Harrison 1989, Longhurst 1991). The importance of the STC as a potential biogenic sink for atmospheric $\mathrm{CO}_{2}$ as proposed by Dower \& Lucas (1993) appears, therefore, to vary seasonally. It should also be noted that the carbon:chlorophyll ratio can vary widely, depending on phytoplankton species composition and nutrient conditions, and may affect substantially the POC flux to depth.

While the results presented here apply only to a small portion of the Southern Ocean, there is growing evidence suggesting that in a large variety of oceanic areas the largest portion of photosynthetically fixed carbon during austral winter is also channelled to the microzooplankton. The predominance of nanoautotrophs (the preferred food particle size of microzooplankton) in Antarctic waters during austral winter has been documented in various studies (Garrison et al. 1993, Kivi \& Kuosa 1994). This suggests that heterotrophic protozooplankton may be the most important sink of winter phytoplankton production. In support of this, a recent study conducted in the Weddell and Scotia. Seas during winter showed that microzooplankton grazing itself was sufficient to prevent biomass accumulation in the water dominated by nanoautotrophs (Garrison et al. 1993).

Shifts in the structure of the food web can alter the magnitude of particulate fluxes to the interior of the ocean (Roman et al. 1993). In the Southern Ocean, a seasonal shift in the contribution of the various size fractions to total chlorophyll concentration may dramatically alter the biological role of the system. During summer, only $\sim 25 \%$ of the photosynthetically fixed carbon is consumed by the microzooplankton (Froneman \& Perissinotto in press). This would suggest that the bulk of the production is processed by meso- and macrozooplankton. Large faecal pellets produced by these grazers, coupled with diel migrations, would result in a net downward flux of POC below the zone of regeneration (Longhurst \& Harrison 1989, Longhurst 1991). Also, changes in sinking of POC are consistent with increases/decreases in macrozooplankton biomass (Roman et al. 1993). During summer, therefore, the model proposed by Huntley et al. (1991), which suggests that up to $80 \%$ of net production is channelled into the larger grazers, appears to apply, suggesting that the biological pump is efficient in the drawdown of atmospheric $\mathrm{CO}_{2}$.

However, during winter, a shift in the size of the phytoplankton results in the bulk of the photosynthetically fixed carbon being channelled into the microzooplanktonic food chain (Garrison et al. 1993). This provides partial support for the proposed model of Moloney (1992) in which it is suggested that up to $60 \%$ of the production is processed by the microbial loop. The net result of this reduction in the POC flux leaving the euphotic zone is that atmospheric $\mathrm{CO}_{2}$ drawdown by the biological pump in the Southern Ocean is reduced during winter. Oceanic features such as warm-core eddies may, however, introduce small mesoscale changes in carbon flux, through the enhancement of phytoplankton productivity usually observed at their edges (Dower \& Lucas 1993).

Acknowledgements. We thank the Department of Environmental Affairs \& Tourism for providing funds and facilities for this study. We are particularly grateful to C. D. McQuaid for his invaluable comments on the manuscript. We are also thankful to the master and crew of the 'S. A. Agulhas' for their co-operation. Finally we express our gratitude to our colleagues, V. Meaton, K. Whittington-Jones, A. Inish and K. Reddy for their assistance at sea and in the laboratory.

\section{LITERATURE CITED}

Albright LJ, Sherr EB, Sherr BF, Fallow RD (1987) Grazing of ciliated protozoa on free and particle attached bacteria. Mar Ecol Prog Ser 38:125-129

Andersen P. Fenchel T (1984) Bacterivory by microheterotrophic flagk!llates un seawater samples. Limnol Oceanogr 30(1): 1:98-202

Angel MV, Fasham MJR (1983) Eddies and biological processes. In: Robinson AR (ed) Eddies in marine science. Springer-Verlag, Berlin, p 492-524

Banse K (1991) Grazing, temporal changes of phytoplankton concentrations, and the microbial loop in the open sea. In: Falkowski PG, Woodhead AD (eds) Primary productivity 
and biochemical cycles in the sea. Plenum Press, New York, p 409-440

Booth BC (1987) The use of autofluorescence for analysing oceanic phytoplankton communities. Botanica Marina 30: $101-108$

Burkill PH, Mantoura RFC, Llewellyn CA. Owens NJP (1987) Microzooplankton grazing and selectivity of phytoplankton in coastal waters. Mar Biol 93:581-590

Capriulo GM, Carpenter EJ (1980) Grazing by 35 to $202 \mu \mathrm{m}$ microzooplankton in Long Island Sound. Mar Biol 56: $319-326$

Comiso JC, MCClam CR, Sullivan CW, Ryan JP, Leondrd CL (1993) Coastal zone color scanner pigment concentrations in the Southern Ocean and relationships to geophysical features. J Geophys Res 98:2419-2451

Deacon GER (1982) Physical and biological zonation in the Southern Ocean. Deep Sea Res 29:1-15

Dower KM, Lucas MI (1993) Photosynthesis-irradiance relationships and production associated with a warm-core ring shed from the Agulhas Retroflection south of Africa. Mar Ecol Prog Ser 95:141-154

Duncombe Rae CM (1991) Agulhas Retroflection rings in the South Atlantic Ocean: an overview. S Afr J Mar Sci 11. $327-344$

El-Sayed SZ (1988) Productivity on the Southern Ocean: a closer look. Comp Biochem Physiol 90(3):489-498

Franks PJS, Wroblewski JS, Flierl GR (1986) Prediction of growth in response to the frictional decay of a warm-core ring. J Geophys Res 91:7603-7610

Froneman $\mathrm{l}^{\mathrm{W}} \mathrm{W}$, Perissinotto $\mathrm{R}$ (in press) Microzooplankton grazing and protozooplankton community structure in the south Atlantic and in the Southern Ocean. Deep Sea Res

Garrison DL (1991) An overview of the abundance and role of protozooplankton in Antarctic waters. J Mar Syst 2:317-331

Garrison DL. Buck KR, Gowing MM (1993) Winter plankton assemblage in the ice edge zone of the Weddell and Scotia Seas: composition, biomass and spatial distributions. Deep Sea Res 40(2):311-338

Gast V (1985) Bacteria as a food source for microzooplankton in the Schlei Fjord and Baltic Sea with special reference to ciliates. Mar Ecol Prog Ser 22:107-120

Gifford DJ (1988) Impact of grazing by microzooplankton in the Northwest Arm of Halifax Harbour, Nova Scotia. Mar Ecol Prog Ser 47:249-258

Hads LW (1982) Improved epifluorescence microscopy for observing planktonic micro-organisms. Ann Inst Oceanogr 58(s): $261-266$

Hattori $H_{1}$ Fukuchi M (1989) Distribution of nano-, micro- and netplankton chlorophyll in the surface water of the Indian Sector of the Southern Ocean, 1985, 1986. Proc NIPR 2: $16-25$

Holm-Hansen O, Riemann B (1978) Chlorophyll-a determination: improvements in methodology. Oikos 30:438-447

Huntley ME, Lopez MDG, Karl DM (1991) Top predators in the Southern Ocean: a major leak in the biological carbon pump. Sclence 253:64-66

Kirchman DL, Keil RG, Simon M, Welschmeyer NA (1993) Biomass and production of heterotrophic bacterioplankton in the oceanic subarctic Pacific. Deep Sea Res 40(5): $967-988$

Kivi K, Kuosa H (1994) Late winter microbial communttes in the western Weddell Sea (Antarctica). Polar Biol 14(6): 398-399

Landry MR, Hassett RP (1982) Estmating the grazing imupaci of marine microzooplankton. Mar Biol 67:283-288

Laubscher RK, Perissinotto R, MCQuaid CD (1993) Phytoplankton production and biomass at frontal zones in the At- lantic sector of the Southern Ocean. Polar Biol 13:471-481 Legendre L, Legendre P (1983) Numerical ecology. Elsevier Scientific Publishing Company, Amsterdam

Longhurst AR (1991) Role of the marine biosphere in the global carbon cycle. Limnol Oceanogr 36(8):1057-1526

Longhurst AR, Harrison WG (1989) The hiological pump: profiles of plankton production and consumption in the upper ocean. Prog Oceanogr 22:47-123

Lutjeharms JRE, Gordon AL (1987) Shedding of an Agulhas ring observed at sea. Nature 325:138-140

Lutjeharms JRE, Valentine HR (1988) On mesoscale ocean eddies at the Agulhas Plateau. S Afr J Sci 84:194-200

McManus GB, Fuhrman JA (1988) Control of marine bactersoplankton populations: measurement and significance of grazing. Hydrobiologia 159:51=62

Michaels AF, Silver MW (1988) Primary production, sinking fluxes and the microbial food web. Deep Sea Res 35(4) $473-490$

Molones CL (1992) Carbon and the Antarctic marne food web. Science 257:259-260

Pakhomov EA, Perissinotto R, McQuald CD (1994) The comparative structure of the macrozooplankton/micronekton communitıes of the subtropical and Antarctic Polar fronts Mar Ecol Prog Ser 111:155-169

Paranjape M (1987) Grazing by microzooplankton in the eastern Canadian Arctic summer. Mar Ecol Prog Ser 40: $239-246$

Peters F (1994) Prediction of planktonic protistan grazing rates. Linınol Oceanogr 39(1):195-206

Pierce RW, Turner JJ (1992) Ecology of planktonic ciliates in marne food webs. Rev Aquat Scl 6(2):139-181

Porter KG, Sherr EB, Sherr BF, Pace M, Sanders RW (1985) Protozoa in planktonic food wels. J Protozool 32(3):409-415

Rassoulzadegan F, Laval-Peuto M. Sheldon RW (1988) Partitioning of food ration of marine clluates between pico and nanoplankton. Hydrobiologia 159:75-88

Reid DF, Karl DM (1990) RACER: bacterial growth, abundance, and loss due to protozoan grazing during the 1989 spring bloom. Antarct J US 25:156-157

Roman MR, Dam HG, Gauzens AL, Napp JM (1993) そooplankton biomass and grazing at the JGOFS Sargasso tha time series station. Deep Sea Res 40(5):883-901

Smith RC, Baker KS (1985) Spatial and temporal patterns in pigment biomass in Gulf Stream warm-core ring $82 \mathrm{~B}$ and its environs. J Geophys Res 90(5):8859-8870

Soka] FJ, Rohlf RR (1969) Statistical tables. Freeman \& Co, San Francisco

Strom SL, Welschmeyer NA (1991) Pigment specific rates of phytoplankion growth and microzooplankton grazing in the subarctic Pacific Ocean. Limnol Ocecnogr 36(1):50-63

Taylor GT, Haberstroh PR (1988) Microzooplankton grazing and planktonic production in the Bransfield Strant during the RACER program. Antarct $J$ LS 25:125-128

Tranter DJ, Parker RR, Cresswell (iR (1980) Are warm-core eddies unproductive? Nature 284:540-, 12

Verity PG, Stoecker DK, Sieracki ME, Nelson JR (1993) Grazing, growth and mortality of microzooplankton during the 1989 North Atlantic spring bloom at $47^{\circ} \mathrm{N}, 18^{\circ} \mathrm{W}$. Deep Sea Res 40(9): 1793-1814

Verity PG, Vernet M (1993) Microzooplankton grazing, pigments, and composition of plankton communities during late spring in two Norwegian fjords. Sarsia 77:263-274

Waterbury JB, Watson SW, Valois FW, Franks DG (1986) Bılugical and coological characterization of the marine unicellular cyanobacterium Synechococcus. In: Platt $\mathrm{T}$, Li WKV (eds) Photosynthetic picoplankton. Can Bull Fish Aquat Sci Ottawa, p 71-120 